ARTICLE

DOI: $10.1038 / s 41467-017-01445-z$

\title{
Nigritoxin is a bacterial toxin for crustaceans and insects
}

Yannick Labreuche ${ }^{1,2}$, Sabine Chenivesse ${ }^{2}$, Alexandra Jeudy ${ }^{2}$, Sophie Le Panse ${ }^{3}$, Viviane Boulo ${ }^{4}$ Dominique Ansquer ${ }^{4}$, Sylvie Pagès ${ }^{5}$, Alain Givaudan ${ }^{5}$, Mirjam Czjzek ${ }^{2}$ \& Frédérique Le Roux ${ }^{1,2}$

The Tetraconata (Pancrustacea) concept proposes that insects are more closely related to aquatic crustaceans than to terrestrial centipedes or millipedes. The question therefore arises whether insects have kept crustacean-specific genetic traits that could be targeted by specific toxins. Here we show that a toxin (nigritoxin), originally identified in a bacterial pathogen of shrimp, is lethal for organisms within the Tetraconata and non-toxic to other animals. X-ray crystallography reveals that nigritoxin possesses a new protein fold of the $\alpha / \beta$ type. The nigritoxin $\mathrm{N}$-terminal domain is essential for cellular translocation and likely encodes specificity for Tetraconata. Once internalized by eukaryotic cells, nigritoxin induces apoptotic cell death through structural features that are localized in the C-terminal domain of the protein. We propose that nigritoxin will be an effective means to identify a Tetraconata evolutionarily conserved pathway and speculate that nigritoxin holds promise as an insecticidal protein.

\footnotetext{
${ }^{1}$ Ifremer, Unité Physiologie Fonctionnelle des Organismes Marins, ZI de la Pointe du Diable, CS 10070, F-29280 Plouzané, France. ${ }^{2}$ Sorbonne Universités, UPMC Paris 06, CNRS, UMR 8227, Integrative Biology of Marine Models, Station Biologique de Roscoff, CS 90074 , F-29688 Roscoff cedex, France. ${ }^{3}$ CNRS, FR 2424, Plateforme Merimage, Station Biologique de Roscoff, Place Georges Teissier, CS 90074, F-29688 Roscoff cedex, France. ${ }^{4}$ Département Lagons, Ecosystèmes et Aquaculture Durables en Nouvelle-Calédonie, IFREMER, BP 2059, 98846 Nouméa cedex, New Caledonia. ${ }^{5}$ UMR 1333 “Diversité, Génomes \& Interactions Microorganismes - Insectes" Université Montpellier 2 - Place Eugène Bataillon, 34095 Montpellier cedex 5, France. Correspondence and requests for materials should be addressed to F.L.R. (email: frederique.le-roux@sb-roscoff.fr)
} 
A rthropods are the most species-rich animal phylum on Earth. They represent more than $85 \%$ of the described animal species and are of tremendous importance to humans as food sources, pollinators, and producers of material goods (e.g., wax, honey, silk) ${ }^{1-3}$. However, some arthropods are also pests and vectors of disease and these interactions are likely to worsen due to range expansions caused by climate change and biological invasions ${ }^{4-6}$. A major challenge is to identify substances that are broadly effective and can be safely applied against known and emergent insect disease vectors and pests. A consensus reconstruction of arthropod relationships, based on molecular, morphological, and fossil data, has proposed that terrestrial insects (Hexapoda) are sister group to aquatic Crustacea and more distantly related to Chelicerates and Myriapods ${ }^{1}$. This suggests that insects and crustaceans (collectively termed the Tetraconata/Pancrustacea group ${ }^{3,}$ ) may share evolutionarily conserved pathways and toxins active against crustaceans may also be efficacious against insects, yet not harmful to more distantly related invertebrates and humans.

We previously identified a putative toxin locus specific to virulent strains of Vibrio nigripulchritudo ${ }^{8,9}$, a bacterial pathogen affecting shrimp in several areas in the Indo-Pacific ${ }^{10}{ }^{11}$. Expression of this gene by a non-virulent $V$. nigripulchritudo strain is sufficient to produce toxic culture supernatant, a characteristic of virulent strains ${ }^{8}$. Interestingly, a portion of this protein (thereafter named nigritoxin) shows significant sequence identity with antifeeding prophage 18 (Afp18), a partially characterized toxin found in the entomopathogenic bacteria Serratia entomophila and in the fish pathogen Yersinia ruckeri ${ }^{12}, 13$, suggesting that nigritoxin may display toxicity against organisms beyond the known target, Litopenaeus stylirostris shrimp.

Here we describe the animal tropism and structure/function relationship of nigritoxin. Nigritoxin is sufficient to mimic the $V$. nigripulchritudo effect in vivo and has lethal activity against crustaceans and insects. X-ray crystallographic studies show that nigritoxin structure represents an entirely unique protein fold and indicate that Afp18 and nigritoxin do not possess the same biological functions. Nigritoxin is comprised of three domains, with the N-terminal domain being essential for cellular translocation and likely encoding specificity for Tetraconata, and the C-terminal domain being involved in cell death induction through apoptotic mechanisms. We then show that nigritoxin is a deadly toxin that targets a Tetraconata evolutionarily conserved pathway.

\section{Results}

Nigritoxin mimics Vibrio effect on shrimp hemocytes. To fulfill the criteria of a bacterial toxin, administration of the purified component at low dose to the animal should elicit key symptoms observed in the host infected with the pathogen. Recombinant purified nigritoxin was intramuscularly injected into L. stylirostris shrimp and we found that $3 \mathrm{ng} \mathrm{g}^{-1}$ body weight $\left(40 \mathrm{fmol} \mathrm{g}^{-1}\right)$ of protein was sufficient to kill $50 \%$ of the tested animals $\left(\mathrm{LD}_{50}\right)$ within 5-10 h (Fig. 1a; Supplementary Fig. 1). In L. stylirostris, infection with $V$. nigripulchritudo results in septicemia ${ }^{10}$ and the only histopathological sign associated to infection is abnormal nuclei in the circulating hemocytes (Supplementary Fig. 2). We thus compared the cytopathogenic effects induced in shrimp hemocytes after injection of either the nigritoxin or $V$. nigripulchritudo by transmission electron microscopy (TEM) (Supplementary Fig. 3). In control animals (shrimp injected with saline or a non-virulent $V$. nigripulchritudo strain), the cells contained normal and intact nuclei with heterochromatin visible in peripheral patches and as a central mass (Supplementary Fig. 3a, d). In shrimp injected by the virulent strain, severe alterations were observed in the hemocytes including membrane disruption, chromatin condensation (pyknosis), and nucleus fragmentation (karyorrhexis), a characteristic of cell undergoing necrosis or apoptosis (Supplementary Fig. 3c). Similar alterations in nuclei were observed in the hemocytes sampled from nigritoxin-injected shrimp (Supplementary Fig. 3b), although more severe cell damage (cell lysis and vacuolization), that correlates to a faster occurrence of mortality, was also observed.

a

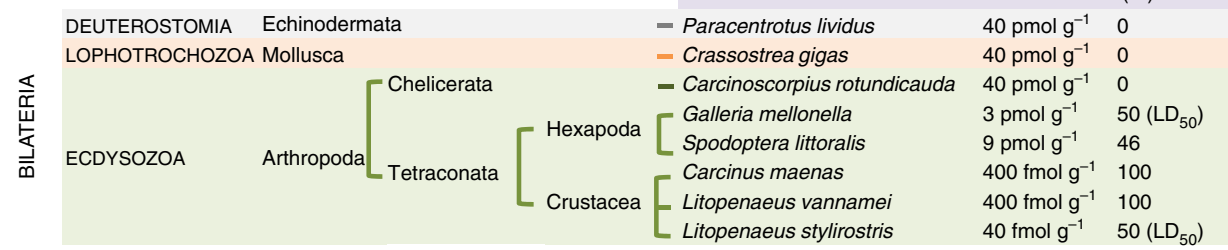

b

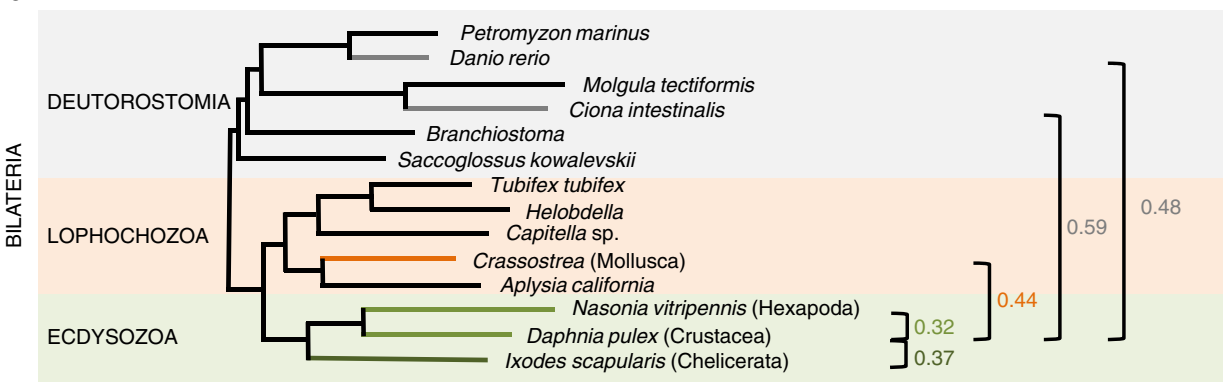

Fig. 1 Toxicity of the nigritoxin for several species of bilateria. a Percentage of mortality obtained after injection of the indicated dose of nigritoxin to different species representative of diverse phyla within the Bilateria. The $\mathrm{LD}_{50}$ was determined for Litopenaeus stylirostris and Galleria mellonella using Probit analysis (Supplementary Fig. 1). b Evolutionary distances in substitutions/site (right side) between Crustacean and Hexapoda (light green), Chelicerata (dark green), Mollusca (orange), and two Deutorostomia Ciona intestinalis and Danio rerio (gray). The tree is adapted from Nosenko et al. ${ }^{52}$ who analyzed a matrix composed of 22,975 homologous amino-acid positions 
a

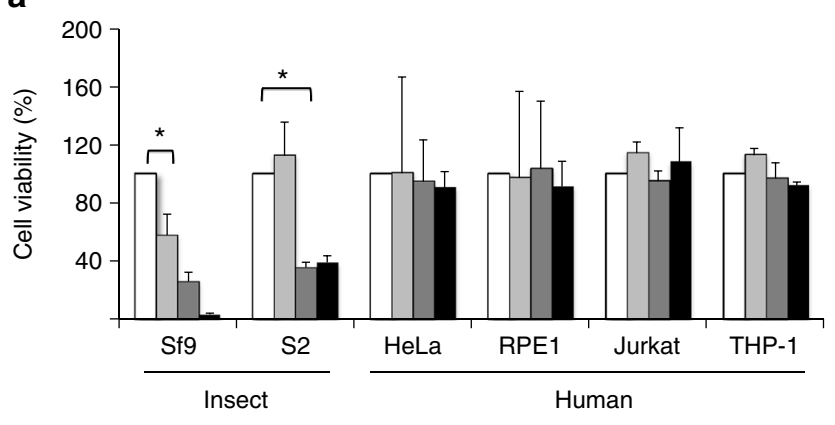

b

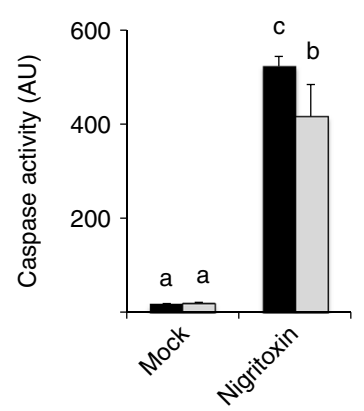

C
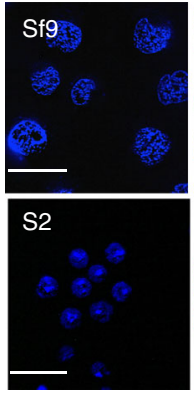
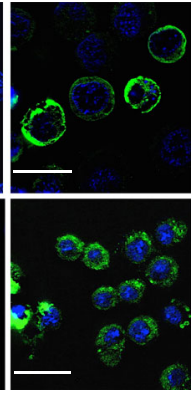
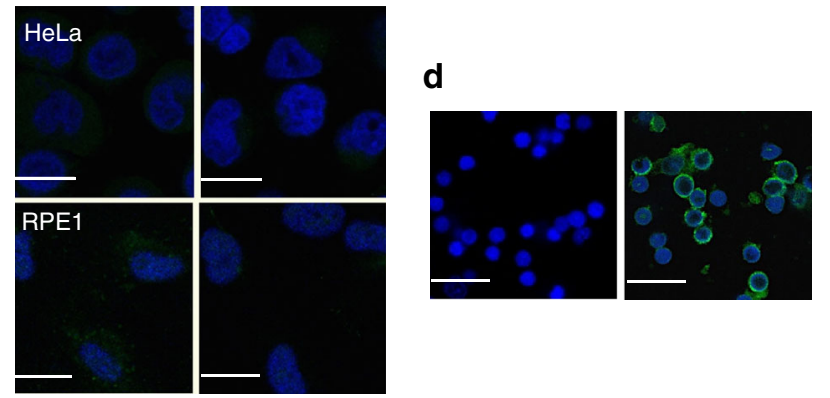

Fig. 2 Cytotoxic activity of the nigritoxin on different cell lines. a Two insect (Sf9 and S2) and four human (HeLa, hTERT RPE-1, Jurkat, and THP-1) cell lines were incubated with nigritoxin $(1.2 \mu \mathrm{M})$ for $0,6,12$, and $24 \mathrm{~h}$ (white, light gray, dark gray, and black bars, respectively). The cytotoxicity expressed in percentage ( $y$-axis) was monitored using Alamar Blue assay. The experiment was performed twice in triplicate and data are presented as mean \pm S.D. A star indicates significant difference between treatment (ANOVA, $p<0.05$ ) b Sf9 and S2 cells (black and gray bars, respectively) were either mock-treated or incubated with $1.2 \mu \mathrm{M}$ nigritoxin for $12 \mathrm{~h}$. Caspase activity was determined using Ac-DEVD-MCA as a substrate. The experiment was performed in triplicate and data are presented as mean \pm S.D. Means with the same letter are not significantly different from each other (Kruskal-Wallis, $p<0.05$ ). c Insect and human cell lines were incubated with nigritoxin $(1.2 \mu \mathrm{M})$ for $6 \mathrm{~h}$, then washed, fixed, and reacted with a specific anti-nigritoxin polyclonal antibody and Alexa Fluor-488-conjugated secondary antibody (green). Nuclei were stained with DAPI. Left image, mock-treated cells; right image, nigritoxin-treated cells. d Primary hemocytes from shrimp Litopenaeus vannamei were treated and analyzed as described in c. Scale bars: $20 \mu \mathrm{M}$

Nigritoxin is lethal for Tetraconata. We explored whether nigritoxin has toxicity against organisms beyond the known target, L. stylirostris. Recombinant nigritoxin or a vehicle control was injected into representatives from diverse invertebrate groups (Fig. 1). Control injections did not result in lethality or observable phenotypes in any tested animals. All crustaceans died within 24 $\mathrm{h}$ following injection of $30 \mathrm{ng} \mathrm{g}^{-1}\left(400 \mathrm{fmol} \mathrm{g}^{-1}\right)$ body weight of protein (Fig. 1a), a dose comparable to that of venom toxins with activity on marine crustaceans ${ }^{14,15}$. Protein was also injected into the hemocoel of larvae from the lepidoptera Galleria mellonella and Spodoptera littoralis. Nigritoxin was found to be lethal to both insects (Fig. 1a), with an $\mathrm{LD}_{50}$ of $270 \mathrm{ng} \mathrm{g}^{-1}\left(3 \mathrm{pmol} \mathrm{g}^{-1}\right)$ for G. mellonella (Supplementary Fig. 1) and $\mathrm{LD}_{46}$ of $788 \mathrm{ng} \mathrm{g}^{-1}(9$ $\mathrm{pmol} \mathrm{g}^{-1}$ ) for S. littoralis (Fig. 1a). On the other hand, nigritoxin did not cause larval mortality when ingested (Supplementary Table 1), although some bacterial toxins have been shown to exert oral toxic capability in lepidoptera ${ }^{16}$. Finally more evolutionary distantly related organisms, i.e., chelicerates, mollusks, and echinoderms (Fig. 1b) were still alive 1 week after injection of up to $3.2 \mu^{-1} \mathrm{~g}^{-1}\left(40 \mathrm{pmol} \mathrm{g}^{-1}\right)$ nigritoxin (Fig. 1a).

Nigritoxin induces apoptotic cell death in insect cells. Further investigation of nigritoxin cytotoxicity was performed using insect and human cell lines. Treatment of the insect cell lines Sf9 and S2 with nigritoxin induced a dose-dependent decline in cell viability, although S2 cells were less sensitive (Supplementary Fig. 4). A dose of 1.2 and $12 \mathrm{nM}$ nigritoxin resulted in significant cell death within $12 \mathrm{~h}$ for Sf9 and S2 cells, respectively. In contrast, up to $1.2 \mu \mathrm{M}$ nigritoxin did not kill a variety of human cell lines (Fig. 2a) nor have an effect on cell cycle progression
(Supplementary Table 2). In insect cells, nigritoxin treatment was associated with cell shrinkage, blebbing, vacuolization, and DNA fragmentation and condensation (Supplementary Fig. 5), suggesting the occurrence of apoptotic cell death. In support of this idea, we observed that treatment of insect cells with the broadspectrum caspase inhibitor, zVAD-fmk, which is known to prevent apoptotic cell death ${ }^{17}$, repressed the cytotoxic effect induced by nigritoxin (Supplementary Fig. 6). Furthermore, nigritoxin treatment of cells resulted in markedly increased caspase activity, as typically observed following induction of apoptosis (Fig. 2b). Caspase induction, like cell death, was less marked in S2 cells than in Sf9 cells treated with nigritoxin. Interestingly, S2 also appeared less sensitive to staurosporine, a well-known initiator of apoptosis (Supplementary Fig. 7). Immunofluorescence analyses show that while two types of cultured insect cells are susceptible to nigritoxin, human cells may be refractory to the toxin due to the inability of the toxin to bind and/or be internalized (Fig. 2c). Cellular translocation of the protein was also observed when shrimp primary hemocytes were incubated with nigritoxin in vitro (Fig. 2d). Finally, time course experiments show that nigritoxin increasingly accumulates in the cytosol of intoxicated Sf9 cells (Supplementary Fig. 8a) with no apparent protein processing (Supplementary Fig. 8b).

Nigritoxin structure represents a unique protein fold. The crystal structure of the nigritoxin was solved by the single anomalous diffusion (SAD) method, using a selenomethioninelabeled protein and refined at $2.1 \AA$ resolution. The overall structural topology of nigritoxin is divided into three globular domains: a N-terminal (aa 17-268), a central (aa 276-460), and 
a
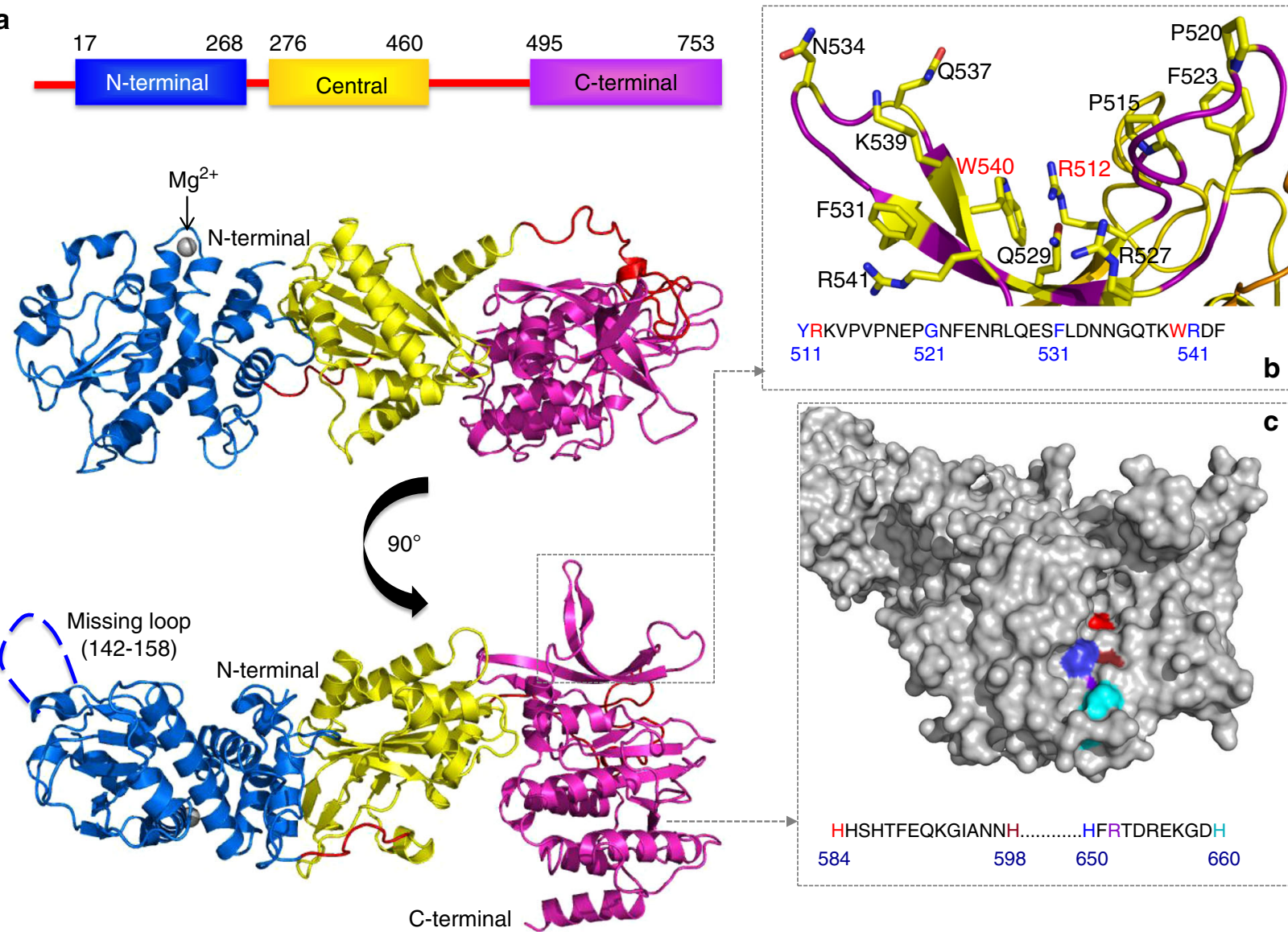

$\begin{array}{llll}511 & 521 & 531 & 541\end{array}$

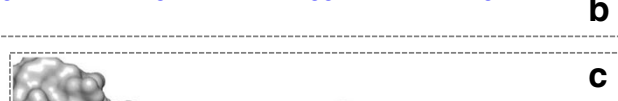

C

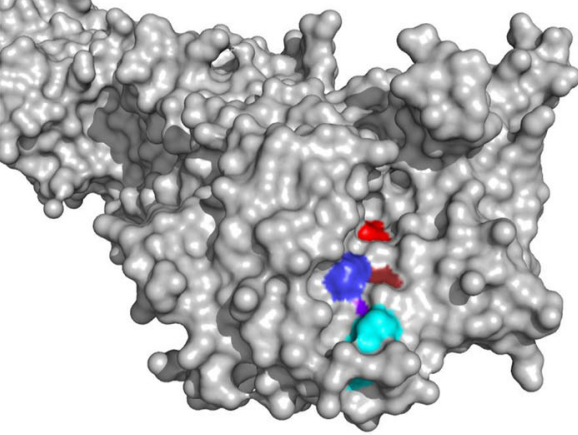

$\begin{array}{lrrr}\text { HHSHTFEQKGIANNH...........HFRTDREKGDH } \\ 584 & 598 & 650 & 660\end{array}$

Fig. 3 Ribbon representation of the overall 3D structure of the nigritoxin molecule. The polypeptide chain is color-coded following the domain architecture (blue: N-terminal; yellow: central; magenta: C-terminal; domains) schematically represented in the upper panel of a. The central panel highlights the 3D domain organization observed in the crystal structure, revealing the $\mathrm{Mg}^{2+}$ bound to a surface loop of the $\mathrm{N}$-terminal domain and the linker regions (orange) (see also Fig. 4). The lower panel displays the 3D structure turned by $90^{\circ}$ around the horizontal axis, showing a disordered loop in the $\mathrm{N}$-terminal domain for which no electron density is visible in the crystal structure. The overall fold as well as those of the three individual domains do not superimpose to any known structure when submitting a "blast against PDB". b Close-up view of a particular structural feature present in the C-terminal domain, which is formed by two loops projecting into the solvent region. The arginine (R512) and tryptophan (W540) residues that stack against each other, as well as some selected residues pointing toward the exterior of the protein are highlighted in stick representation. c Surface representation of the C-terminal domain (gray), highlighting a local groove, in which a series of histidine and arginine residues (surface color corresponds to the color of the residue in the sequence extract) form a large patch that could represent a region important for the biological function. The patch is localized in front of a cavity (Supplementary Fig. 12)

C-terminal domain (aa 495-753) (Fig. 3a; Supplementary Fig. 9). A surface loop in the N-terminal domain contains a metal ion that was modeled as $\mathrm{Mg}^{2+}$, since this ion is present in the crystallization conditions (Fig. 4). However, treatment of Sf9 cells with the chelating agent EDTA did not substantially alter the cytotoxic effect induced by nigritoxin (Supplementary Fig. 10), suggesting that the role of $\mathrm{Mg}^{2+}$ coordination is structural and not important for the activity. The C-terminal domain of nigritoxin contains two interesting and not yet described structural features: residues 512-544 form two large loops, each composed of two antiparallel strands that project out of the globular surface like "rabbit ears" (Fig. 3b; Supplementary Fig. 11). The bases of these protruding loops appear to be stabilized through a hydrophobic stacking of the side chain of Arg512 with the side chain of Trp540. The second feature is located on the concave side of the second, larger $\beta$-sheet, where four histidine residues and one arginine are concentrated in a groove with maximal distance of $10 \AA$ (Fig. 3c; Supplementary Fig. 12) creating a large and positively charged patch at the protein surface that has yet to have a defined biological function. Comparative analyses with Blast against PDB, DALI, Phyre2, or ProFunc revealed that neither the structure of full-length nigritoxin nor that of its individual subdomains resembles any known fold or protein structure, meaning that to date this protein structure is an "orphan", making the identification of an active site difficult. Consequently, the entire nigritoxin protein can be considered to possess a new protein fold, and following the classification of CATH (http://www. cathdb.info/) belongs to the $\alpha / \beta$ class. According to the statistics at the RCSB Protein Data Bank (www.rcsb.org/pdb/statistics/), new folds have not been reported or deposited in the last 4 years.

Nigritoxin structural domains have distinct roles. Site directly mutated and/or truncated forms of nigritoxin were used to define functions for its constituent regions. Double substitution with alanine of the two amino acids (Arg512 and Trp540) suspected to be involved in the stabilization of the protruding loops did not affect toxicity to Sf9 cells (Fig. 5a). On the other hand, deletion of the protruding loops eliminated toxicity, as did replacement with alanine of two histidine residues (His598 and His650) that are suspected of contributing to a functional "hotspot" (Fig. 5a). None of these mutations prevented protein internalization 


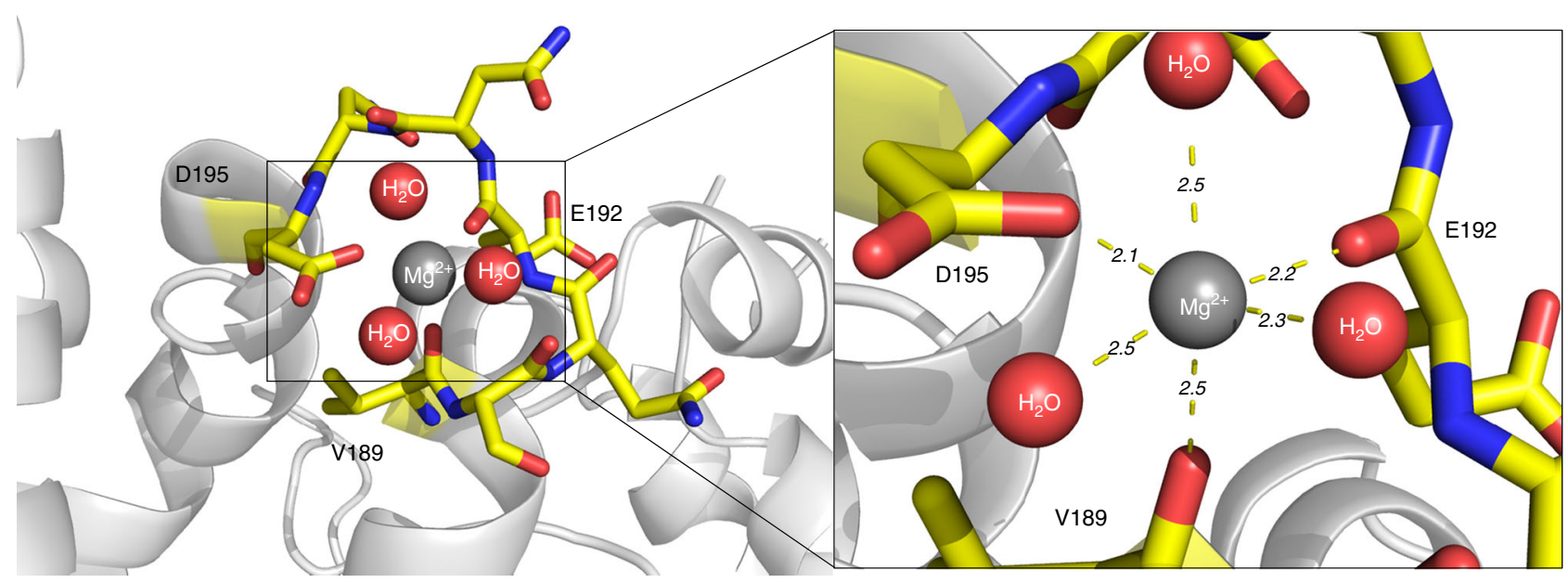

Fig. 4 Coordination sphere of the magnesium ion. The residues of the loop carrying the $\mathrm{Mg}^{2+}$ binding site are represented as sticks. The $\mathrm{Mg}^{2+}$ ion is coordinated by the main chain carboxyl groups of V189 and E192, and the side chain carboxyl group of D195. The octahedral coordination sphere is completed by three water molecules. The right panel shows a close-up view of the binding site, indicating the distances to the coordinating atoms in $\AA$

(Fig. 5b) and altered the folding of the proteins as measured by dynamic light scattering. These data suggest that toxicity is mediated at least in part through nigritoxin's C-terminal domain, as does the fact that no toxicity was induced by constructs lacking this domain. However, the C-terminal domain was not sufficient to induce Sf9 cell death (Fig. 5a). Immunofluorescence assays suggest that this may reflect a role for nigritoxin's N-terminal domain in toxin internalization, as only polypeptides that included the $\mathrm{N}$-terminal domain showed marked intracellular accumulation (Fig. 5b). The truncated forms of nigritoxin were similarly detected by sodium dodecyl sulfate (SDS)-polyacrylamide gel electrophoresis (PAGE) and Western blot with polyclonal anti-nigritoxin antibodies, showing that these results were not due to protein instability or lack of detection by the antibodies (Supplementary Fig. 13). Thus, our working hypothesis is that the toxin's structural domains have distinct roles: the $\mathrm{N}$-terminal domain mediates toxin internalization by target cells, while the C-terminal domain is necessary to induce cell death through apoptosis.

Nigritoxin and Afp18 act by distinct mechanisms. A portion of nigritoxin shows substantial sequence identity $(\approx 28 \%)$ with Afp18, the toxin component of the phage tail-derived protein translocation system identified in several bacterial pathogens ${ }^{12,13}$. Similarity is limited to nigritoxin's N-terminal domain (aa 17-228) and part of the middle domain (aa 276-373), and it corresponds to only a fragment of Afp18 (Supplementary Fig. 14). Highly conserved amino acids are largely localized within the hydrophobic core of the nigritoxin structure, suggesting that they may contribute more to maintenance of fold structure than to specific toxin activity (Supplementary Figs. 15, 16). Notably, Afp18 lacks homology to the region associated with nigritoxin toxicity, and nigritoxin likewise lacks homology to Afp18's Cterminal domain, which encodes a glycosyltransferase associated with inhibition of RhoA activation in Y. ruckeri ${ }^{13}$. Collectively, these data suggest that nigritoxin and Afp18 toxicity are produced through distinct mechanisms. Toxin internalization processes also appear to differ: in contrast to nigritoxin, which can enter host cells, Afp18 internalization is mediated by a phage tail-like particle with structural similarity to R-type pyocins ${ }^{12}$. Genes encoding such structures could not be identified in the $V$. nigripulchritudo genomes ${ }^{8}$. Thus, although Afp18 and nigritoxin may have a common evolutionary origin, subsequent domain shuffling and divergent evolution appear to have resulted in distinct roles for these proteins.

\section{Discussion}

Combining experimental infection, cellular, and structural biology data, we demonstrated that nigritoxin is a potent toxin with lethal effect for crustaceans and insects. Our results suggest that nigritoxin targets a pathway that has been evolutionarily conserved between Crustacea and Hexapoda, in line with the Tetraconata (Pancrustacea) hypothesis for arthropod phylogeny. Although it is necessary to confirm these data by testing more animal species in experimental infection, further exploration of the in vitro cytotoxicity of nigritoxin confirmed that a crustaceanspecific receptor and/or means of translocation is conserved in insect cells and targeted by the N-terminal domain of nigritoxin, which is required for its internalization.

Nigritoxin not only possesses a new protein fold but also seems to act by an original mechanism leading to apoptotic cell death ${ }^{18}$. Nigritoxin is secreted by $V$. nigripulchritudo through an as yet unknown process ${ }^{8}$. As the purified protein induces toxicity, nigritoxin acts as a homoprotein and does not require a secretion system to be delivered into the eukaryotic host cell ${ }^{19}$ nor need to be transported by outer membrane vesicles ${ }^{20}$. Nigritoxin does not disrupt membrane integrity by forming pores ${ }^{21}$. The target eukaryotic cells rapidly internalize nigritoxin, which then accumulates in the cytoplasm with no apparent protein degradation or processing. This suggests an intracellular mode of action of the nigritoxin. Consequently nigritoxin may not act as a host receptor agonist or antagonist, triggering signal transduction pathways ${ }^{22}$, although accumulating evidences revealed that the endocytosis of receptor-ligand contributes to generate cellular signals ${ }^{23}, 24$. Finally although nigritoxin causes chromatin damage, it is not translocated into the nuclear compartment, such as cytolethal distending toxins ${ }^{25}$. The primary target of nigritoxin may within the cytoplasm and could involve caspases, the cellular executioners of apoptosis ${ }^{26}$. The C-terminal domain and more particularly the "rabbit ears" and functional "hotspot" are essential for nigritoxin cytoplasmic activity although a role of the two other domains cannot be excluded based on the present data. Hence several relevant questions need to be further addressed, such as: (i) does internalization implicate a surface receptor(s) and/or lipid raft? (ii) does internalization occur via endocytosis? (iii) what is the route of the toxin within the cytoplasm (intracellular 


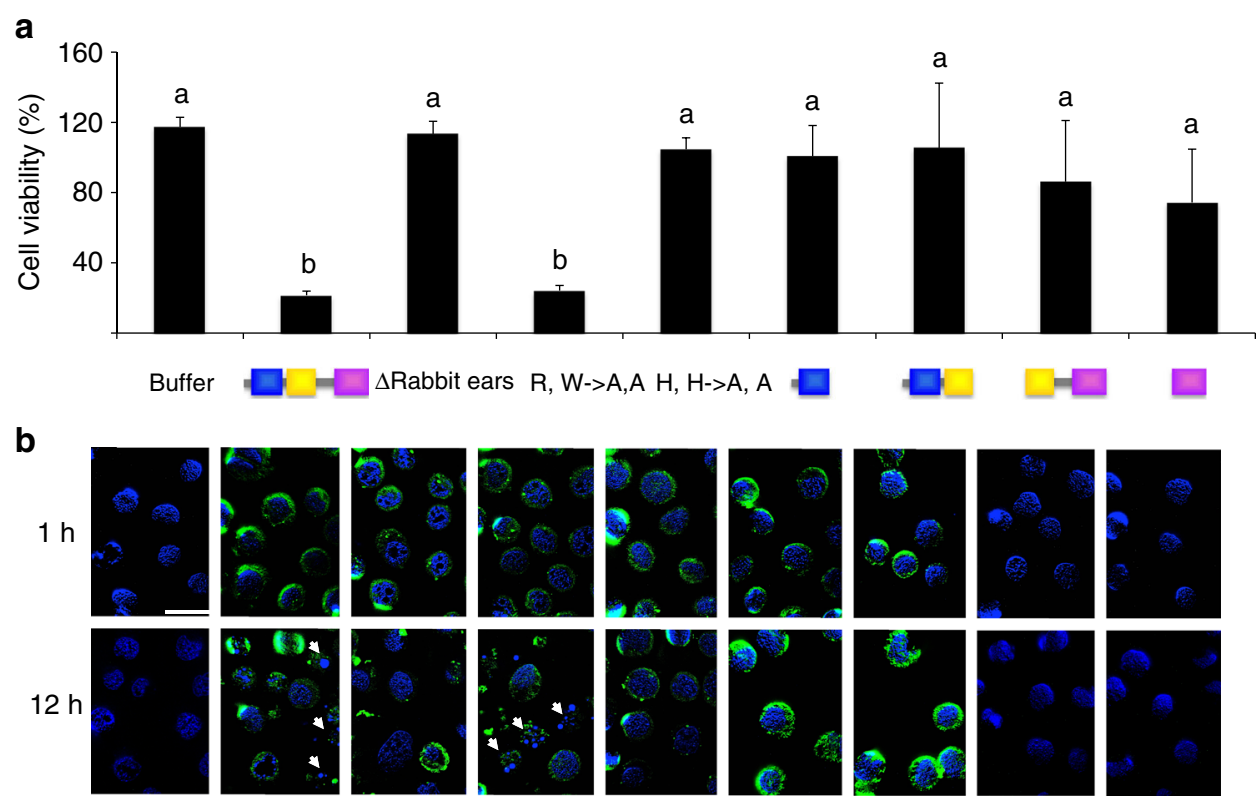

Fig. 5 Functional role of nigritoxin domains. a Cytotoxic activity of wild type (domains schematically represented in blue: N-terminal; yellow: central; magenta: C-terminal), truncated forms, and mutants ( $\Delta$ rabbit ears: deletion of the protruding loops; R,W->A,A: Arg512 and Trp540 replaced by two Ala; $\mathrm{H}, \mathrm{H}->\mathrm{A}, \mathrm{A}$ : His598 and His650 replaced by two Ala) of nigritoxin on insect cells. Sf9 cells were incubated with $1.2 \mu \mathrm{M}$ of truncated forms or mutants of nigritoxin or with the same volume of protein suspension buffer for $12 \mathrm{~h}$. The cytotoxicity was monitored using Alamar Blue assay. For each condition, the cell viability was compared to mock (untreated) cells set at $100 \%$ viability and expressed in percentage ( $y$-axis). The experiment was performed twice in triplicate and data are presented as mean \pm S.D. Means with the same letter are not significantly different from each other (Kruskal-Wallis, $p<0.05)$. $\mathbf{b}$ Cellular localization of wild type, truncated, and mutant versions of nigritoxin in Sf9 cells. Cells were incubated with purified proteins/fragments (1.2 $\mu$ M) for 1 and $12 \mathrm{~h}$, fixed and detected by immunochemistry. Nuclei are stained in blue with DAPI. White arrows indicate nuclei damages. Scale bars: $20 \mu \mathrm{M}$

trafficking, target organelles such as mitochondria, target molecules)?

Typical signs of apoptosis were also observed in hemocytes of nigritoxin-injected shrimp and mimic cytopathological symptoms observed in animal infected by $V$. nigripulchritudo. This suggests that nigritoxin is a major virulence factor of $V$. nigripulchritudo and the hemocyte its primary target. In support of this assumption, the nigritoxin was shown to be only active when delivered into the animal circulatory system, unlike some bacterial toxins displaying oral toxicity, such as the 3D-Cry toxins, which interact with specific receptors located on the insect gut epithelium leading to pore formation ${ }^{27,28}$ or the PirAB ${ }^{\mathrm{vp}}$ toxin in shrimp ${ }^{29}$. This may be explained either by the failure of the toxin to cross the peritrophic barrier, a chitin-rich matrix covering the digestive tube of insects and crustaceans, or more plausibly by the fact that gut cells do not represent the primary target of the nigritoxin.

The nigritoxin $\mathrm{LD}_{50}$ appears to be of the same order of magnitude as that of other toxins tested in marine invertebrates ${ }^{14}, 15$ or in insects 30,31 . Targeting a broad range of insect species represents an alternative to the narrow activity spectrum of commercialized biological insecticides such as Bacillus thuringiensis toxins $(\mathrm{Bt})^{28}$, which are not toxic to some key insect pests, including the hemipteran (e.g., sap-sucking insects) pests ${ }^{32}$. We speculate that nigritoxin holds promise as an insecticidal protein but delivery systems have to be devised to access its target site, i.e., the animal circulatory system.

\section{Methods}

Bacterial strains. The V. nigripulchritudo strain SFn1 (virulent) and VN110 plasmid cured derivative (non-virulent) ${ }^{9}$ were grown in marine broth or on marine agar (Difco) at $30^{\circ} \mathrm{C}$. Escherichia coli strain TOP10 (Invitrogen) was used as plasmid host for cloning. E. coli strains BL21 (DE3) and B834 (DE3) (Novagen) were used for protein and selenomethionine-substituted protein production, respectively (Supplementary Table 3 ). Strains were grown at $37^{\circ} \mathrm{C}$ in Luria-Bertani (LB) broth or agar (Difco) with $100 \mu \mathrm{g} \mathrm{ml}^{-1}$ of carbenicillin, or in ZYP 5052 (for $1 \mathrm{l}$ :
$928 \mathrm{ml} \mathrm{ZY}\left(10 \mathrm{~g} \mathrm{l}^{-1} \mathrm{~N}\right.$-Z-amine AS, $5 \mathrm{gl}^{-1}$ yeast extract); $1 \mathrm{ml} 1 \mathrm{M} \mathrm{MgSO} 4 ; 1 \mathrm{ml}$ $1000 \times$ metal mix $\left(50 \mathrm{mM} \mathrm{FeCl}_{3}, 20 \mathrm{mM} \mathrm{CaCl}, 10 \mathrm{mM}\right.$ each of $\mathrm{MnCl}_{2}$ and $\mathrm{ZnSO}_{4}$, and $2 \mathrm{mM}$ each of $\mathrm{CoCl}_{2}, \mathrm{CuCl}_{2}, \mathrm{NiCl}_{2}, \mathrm{Na}_{2} \mathrm{MoO}_{4}, \mathrm{Na}_{2} \mathrm{SeO}_{3}$, and $\mathrm{H}_{3} \mathrm{BO}_{3}$ in $~ 50$ $\mathrm{mM} \mathrm{HCl}$ ); $20 \mathrm{ml} 50 \times 5052$ ( $25 \%$ glycerol, $2.5 \%$ glucose, and $10 \% \alpha$-lactose); $50 \mathrm{ml}$ $20 \times \mathrm{NPS}\left(0.5 \mathrm{M}\left(\mathrm{NH}_{4}\right)_{2} \mathrm{SO}_{4} ; 1 \mathrm{M} \mathrm{KH}_{2} \mathrm{PO}_{4} ; 1 \mathrm{M} \mathrm{Na}_{2} \mathrm{HPO}_{4}\right) ; 1 \mathrm{ml}$ carbenicillin 50 $\mathrm{mg} \mathrm{ml}^{-1}$ ) or PASM $5052^{33}$ (for $1 \mathrm{l:} 721 \mathrm{ml}$ sterile water; $0.8 \mathrm{ml} 1 \mathrm{M} \mathrm{MgSO}_{4} ; 0.8 \mathrm{ml}$ $1000 \times$ metal mix; $16 \mathrm{ml} 50 \times 5052 ; 40 \mathrm{ml} 20 \times \mathrm{NPS} ; 100 \mathrm{nM}$ vitamin $\mathrm{B}_{12} ; 200 \mu \mathrm{g} \mathrm{ml}$ -1 of each of 17 amino acids (no C, Y, and M); $10 \mu \mathrm{g} \mathrm{ml}^{-1}$ methionine; $125 \mu \mathrm{g} \mathrm{ml}^{-1}$ Se-Met; $1 \mathrm{ml}$ carbenicillin $50 \mathrm{mg} \mathrm{ml}^{-1}$ ) medium for induction of protein expression in BL21 (DE3) or B834 (DE3) strains, respectively.

Molecular biology. The nigritoxin gene (CDS) was PCR amplified using primer pair 090413-2/090413-3 (Supplementary Table 4), strain SFn1 DNA as target and Herculase II fusion proof reading polymerase according to the manufacturer instructions (Agilent). The amplicon was digested by Bam HI and XhoI and cloned into the pFO4 plasmid ${ }^{34}$ (modified from pET15b, Novagen, USA) that contains an histidine tag at the $\mathrm{N}$-terminal for affinity purification. Nigritoxin N-terminal domain (aa 1-270), N-terminal, and central domain (aa 1-457) and C-terminal domain (aa 486-757) were generated following the same procedure using primer pairs 090413-2/290914-2, 090413-2/290914-3, and 290914-1/090413-3, respectively. Cloning of the central and C-terminal domain (aa 271-757) into the pFO4 plasmid was performed using the Gibson assembly method according to the manufacturer's instructions (New England Biolabs, NEB) using primer pairs 200315-3/200315-5 and 200315-1/200315-2 to amplify the nigritoxin-targeted region and $\mathrm{pFO} 4$, respectively. Mutagenesis was performed by Gibson assembly using primers $060515-2 /-3$ ( $\operatorname{Arg}_{512}$ to Ala), 060515-4/-5 ( $\operatorname{Trp}_{540}$ to Ala), 310816-3/4 (His $_{598}$ to Ala), 310816-5/-6 ( His $_{650}$ to Ala), 310816-11/-12 ( $\mathrm{Thr}_{510}$ to $\mathrm{Arg}_{541}$ to GGG), and primers (090413-2/090413-3) spanning the gene. All constructs were confirmed by sequencing prior to BL21(DE3) transformation.

Purification of recombinant proteins. After expression in $200 \mathrm{ml} \mathrm{ZYP} 5052$ at 20 ${ }^{\circ} \mathrm{C}$ for 3 days, recombinant proteins were purified by resuspending cells in $4 \mathrm{ml}$ suspension buffer (50 mM Tris pH 8.0, 25\% sucrose, $100 \mu \mathrm{g} \mathrm{ml}^{-1}$ lysozyme) and incubating $10 \mathrm{~min}$ at $\mathrm{RT}^{35}$. Next $8 \mathrm{ml}$ of lysis solution $(20 \mathrm{mM}$ Tris $\mathrm{pH} 7.5,100$ $\mathrm{mM} \mathrm{NaCl}, 1 \%$ Triton X-100, 1\% deoxycholate) supplemented with antiprotease (complete, EDTA-free, Roche) was added and incubated stirring at $4{ }^{\circ} \mathrm{C}$ for $10 \mathrm{~min}$. Finally, $\mathrm{MgCl}_{2}$ and $\mathrm{DNase}$ were added at $5 \mathrm{mM}$ and $6 \mathrm{U} \mathrm{ml}^{-1}$, respectively, and the lysate was incubated for $20 \mathrm{~min}$ at RT prior to $45 \mathrm{~min}$ centrifugation at $13,865 \times \mathrm{g}$ and $4{ }^{\circ} \mathrm{C}$. The $0.2 \mu \mathrm{m}$-filtered supernatant was run on a $5 \mathrm{ml}$ HisTrap HP column (GE healthcare Life Science) previously equilibrated with buffer A $(20 \mathrm{mM}$

NaPhosphate $\mathrm{pH} 7.4,290 \mathrm{mM} \mathrm{NaCl}, 5 \mathrm{mM}$ imidazole), then washed with buffer A 


\section{Table 1 Data collection and refinement statistics for the crystal structures of the Se-Met-labeled and native nigritoxin molecules}

Nigritoxin_Semet Nigritoxin_native

\begin{tabular}{|c|c|c|}
\hline \multicolumn{3}{|l|}{ Data collection } \\
\hline Beamline & PROXIMA 2 & ID29 \\
\hline Wavelength(s) & 0.9793 & 1.0332 \\
\hline Space group & 123 & 123 \\
\hline Unit cell & $a=b=c=183.32 \AA$ & $a=b=c=185.16 \AA$ \\
\hline Resolution range $^{\mathrm{a}}(\AA)$ & $\begin{array}{l}45.83-3.02 \\
(3.20-3.02)\end{array}$ & $\begin{array}{l}65.46-2.10 \\
(2.21-2.10)\end{array}$ \\
\hline Total data & 449,101 & 205,825 \\
\hline Unique data & 39,002 & 60,874 \\
\hline Completeness (\%) & $99.9(99.8)$ & $99.3(97.7)$ \\
\hline Mean $I / \sigma(I)$ & $15.13(1.90)$ & $13.3(3.3)$ \\
\hline$R_{\mathrm{sym}}{ }^{\mathrm{b}} ; R_{\mathrm{pim}}{ }^{\mathrm{c}}(\%)$ & $\begin{array}{l}0.22(1.26) ; 0.05 \\
(0.20)\end{array}$ & $\begin{array}{l}0.06(0.39) ; 0.03 \\
(0.21)\end{array}$ \\
\hline Redundancy & 11.5 & 3.4 \\
\hline Anom CC & 54 & - \\
\hline Anom FOM & 0.353 & - \\
\hline Refinement statistics & & \\
\hline Resolution range & & $\begin{array}{l}70.00-2.1 \\
(2.155-2.10)\end{array}$ \\
\hline Unique reflexions & & $57,805(4120)$ \\
\hline Reflexions $R_{\text {free }}$ & & 3069 (234) \\
\hline$R / R_{\text {free }}(\%)$ & & $\begin{array}{l}22.9 / 26.5 \\
(25.3 / 29.6)\end{array}$ \\
\hline RMSD bond lengths & & $0.019 \AA$ \\
\hline RMSD bond angles & & $1.95^{\circ}$ \\
\hline Overall B factor $\left(\AA^{2}\right)$ & & 48.78 \\
\hline B factor: molecule $A\left(\AA^{2}\right)$ & & 40.74 \\
\hline B factor: solvant $\left(\AA^{2}\right)$ & & 57.67 \\
\hline
\end{tabular}

Values in parentheses concern the high-resolution shell

${ }^{b_{R}} R_{\text {sym }}=\Sigma||-I_{\text {av }}|/ \Sigma| \|$, where the summation is over all symmetry equivalent reflections ${ }^{b} R_{\text {sym }}=\Sigma||-l_{\text {av }}|/ \Sigma| \mid l$, where the summation is over al
${ }^{c} R_{\text {pim }}$ corresponds to the multiplicity weighted $R_{\text {sym }}$

and eluted using a gradient of 1-100\% buffer B (20 mM NaPhosphate pH 7.4, 290 $\mathrm{mM} \mathrm{NaCl}, 0.5 \mathrm{M}$ imidazole). The protein was concentrated using an Amicon stirred cell concentrator (molecular weight cutoff $10 \mathrm{kDa}$ ), passed through a Superdex S200 column (GE healthcare Life Science), eluted in Hepes $20 \mathrm{mM} \mathrm{NaCl}$ $150 \mathrm{mM} \mathrm{pH} \mathrm{7.4,} \mathrm{and} \mathrm{finally} \mathrm{concentrated} \mathrm{as} \mathrm{described} \mathrm{above.} \mathrm{Proteins} \mathrm{were}$ assessed as having $>95 \%$ purity by SDS-PAGE. The concentration was calculated from the $\mathrm{A}_{280}$ and the extinction coefficient calculated using the ProtParam tool from ExPASy $\left(\varepsilon_{0.1 \%}\right.$ of 0.69$)$. For 3D structure resolution, the seleno-L-methionine (Se-Met) labeling procedure was performed by growing B834 (DE3) cells in 11 of PASM 5052 medium, using the same purification method except that the final buffer contained $5 \mathrm{mM}$ of tris (2-carboxyethyl) phosphin. The recombinant proteins used for structural determination and functional assays retained the histidine tag without impacting the structure and function of the protein.

Crystallization and crystal structure determination. Single crystals of native and Se-Met-labeled nigritoxin $\left(10 \mathrm{mg} \mathrm{ml}^{-1}\right)$ were grown by the hanging drop method over a reservoir containing $100 \mathrm{mM}$ Bis-Tris propane buffer at $\mathrm{pH} 8.5,24 \%(\mathrm{w} / \mathrm{v})$ PEG 3350, 0.1 M sodium fluorate, and $100 \mathrm{mM}$ Bis-Tris propane buffer at $\mathrm{pH} 8.5$, $20 \%(\mathrm{w} / \mathrm{v}$ ) PEG 3350, $0.1 \mathrm{M}$ sodium fluorate. To collect data at cryogenic temperature, crystals were rapidly soaked in a cryo buffer that was identical to the reservoir solution supplemented with $10 \%$ glycerol and frozen in a stream of nitrogen at $100 \mathrm{~K}$. Nigritoxin diffraction data were collected at the European Synchrotron Radiation Facility (ESRF, Grenoble, France) on beamline ID29 (native data) and at the synchrotron SOLEIL (Saint-Aubin, France) on beamline PROXIMA2 (Se-Met-labeled nigritoxin) at the selenium peak with a wavelength of $0.9793 \AA\left(f^{\prime}=-8.09, f^{\prime}=6.74\right)$. The data were processed using MOSFLM ${ }^{36}$, Pointless $^{37}$ was used to determine the spacegroup and the data were scaled using SCALA $^{38,} 39$ within the CCP4 suite of programs (Collaborative Computational Project ${ }^{40}$ ). PrepHAData was used to convert the mtz to SHELXS format and SHELX_CDE was used to identify the 10 Se subsites through SAD phasing ${ }^{41}$. Finally, the program PARROT ${ }^{42}$ provided an interpretable electron density map with an overall figure of merit of 0.83 after 15 cycles. Automatic model building with BUCCANNEER ${ }^{43}$ correctly built $\sim 70 \%$ of the polypeptide chain. This model was then used to solve the structure of the native data set at $2.1 \AA$ by molecular replacement and went through an iterative process of refinement using
REFMAC $5^{44}$, and model building with $\mathrm{COOT}^{45}$ to construct the missing parts. Further data collection and refinement statistics are provided in Table 1.

To compare the folding state of the different mutant forms of nigritoxin, the polydispersity and hydrodynamic particle radius of the heterologously (and solubly) expressed proteins were measured by dynamic light scattering (Malvern Zetasizer). The wild-type protein showed no aggregation at all and the hydrodynamic radius ( $\mathrm{Rh}$ ) was measured to be $11.9 \mathrm{~nm}$; the two mutant proteins showed some aggregation, but more than $98 \%$ of the volume were unaggregated particles with a Rh of 8.6 and $7.8 \mathrm{~nm}$, for the "rabbit-ears" and double-histidine mutants, respectively, indicating a majority of folded protein particles in solution. In addition, the elution times in size exclusion chromatography were in the same range for the wild-type protein and the two mutants (between 51 and $73 \mathrm{~min}$ ).

Animal assays. Shrimp L. stylirostris and Litopenaeus vannamei were obtained from Ifremer facilities in New Caledonia and the Roscoff Biological Station (France), respectively. Shore crabs Carcinus maenas and sea urchins Paracentrotus lividus were collected at a subtidal sampling site at the Roscoff Biological Station. Pacific oysters Crassostrea gigas were obtained from the Ifremer facility located at Argenton (France). Horseshoe crabs Carcinoscorpius rotundicauda were obtained from a commercial hatchery (Challet-Herault Aquariophilie, Nuaillé, France). The $S$. littoralis corn variant and the greater wax moth $G$. mellonella larvae (University of Montpellier) were reared on artificial $\operatorname{diet}^{46}$ at $23^{\circ} \mathrm{C}$ or with honey and pollen at $28^{\circ} \mathrm{C}$, respectively. Experiments were performed on last instar of G. mellonella or sixth instar (one-day-old) of S. littoralis larvae.

For L. stylirostris, G. mellonella, and S. littoralis different concentrations of nigritoxin $\left(0.01 \mathrm{ng}-1.2 \mu \mathrm{g}\right.$ protein $\left.\mathrm{g}^{-1}\right)$ were tested, and each dose was injected into 10-20 animals ${ }^{9,47}$. As a control, one group of 10-20 animals was injected with the protein solubilization buffer $(20 \mathrm{mM}$ Hepes $\mathrm{pH} 7.4,150 \mathrm{mM} \mathrm{NaCl})$. The surfaces of insect larvae were sterilized with $70 \%$ ( $\mathrm{vol} / \mathrm{vol}$ ) ethanol and larvae were injected through the cuticle into the hemocoel using a Hamilton syringe with $20 \mu \mathrm{l}$ of the appropriate dilution of nigritoxin. These experiments were performed at least twice. The calculation of $\mathrm{LD}_{50}$ was performed using Probit Analysis ${ }^{48}$, a type of regression used to analyze binomial response variables.

Other animals (10-20 animals per treatment) were injected using a 25-gauge needle with a solution of nigritoxin (depending on the animal $30 \mathrm{ng}-3 \mu \mathrm{g} \mathrm{g}^{-1}$ ) or protein solubilization buffer as a control. Shore crabs were injected through the arthroidial membrane at the base of the walking legs, sea urchins into the coelomic cavity near the mouth region, oysters in the adductor muscle, and horseshoe crabs through the arthrodial membrane, directly into the cardiac sinus. Experiments were performed twice.

For per-os inoculation of nigritoxin, after killing a control non-infected $L$ stylirostris shrimp, the cuticle was removed from the abdominal segment and the muscle tissues were cut into $500 \mathrm{mg}$ pieces. Each portion was subsequently injected either with $5 \mu \mathrm{g}$ nigritoxin or an equivalent volume of protein solubilization buffer and kept at $4^{\circ} \mathrm{C}$ for $1 \mathrm{~h}$. Acclimated shrimp were starved for 1 day before feeding individually housed shrimp with a portion of tissues either injected with nigritoxin or buffer.

For histopathological analysis, L. stylirostris shrimp were infected by immersion to mimic natural route of infection. Immersion challenges were performed in 1001 of filtered and aerated seawater containing $10^{5} \mathrm{cfu} \mathrm{ml}^{-1}$ of the considered vibrio strain (virulent strain SFn1, non-virulent strain VN1109). Following a $2 \mathrm{~h}$ challenge, shrimp were transferred to 1001 tanks filled with filtered seawater, aerated and held at $27^{\circ} \mathrm{C}$. Three replicate tanks of 35 shrimp were used for each treatment. At different time points, two shrimp from each tank were randomly sampled and fixed with Davidson fixative for $48 \mathrm{~h}$. Tissues were then processed following standard histological methods and stained with hematoxylin and eosin (Histalim, Montpellier, France).

For electronic transmission microscopy, L. stylirostris shrimp (3 replicate aquaria with 20 shrimp in each for each condition) were injected with a $100 \mu \mathrm{l}$ volume of either a virulent strain of $V$. nigripulchritudo (SFn1, $700 \mathrm{cfu}$ per animal), a non-virulent $V$. nigripulchritudo (strain VN110, $1000 \mathrm{cfu}$ per animal), nigritoxin ( $\mathrm{LD}_{50}, 3 \mathrm{ng} \mathrm{g}^{-1}$ body weight) or saline as a control. At the onset of mortality, shrimp hemolymph was collected using a 25-gauge needle containing an anticoagulant solution $(2 \% \mathrm{NaCl}, 0.1 \mathrm{M}$ glucose, $30 \mathrm{mM}$ sodium citrate, $26 \mathrm{mM}$ citric acid, $10 \mathrm{mM}$ EDTA $)^{49}$ and cells pelleted by centrifugation $(800 \times g$ for $10 \mathrm{~min}$ at $4{ }^{\circ} \mathrm{C}$ ) before fixation.

Electronic transmission microscopy. Shrimp hemocytes were fixed in $5 \%$ glutaraldehyde in $0.2 \mathrm{M}$ sodium cacodylate $(\mathrm{pH} 7.4)$ and $0.25 \mathrm{M}$ sucrose $^{50}$. The samples were then rinsed in a series of buffer solutions containing graded concentrations of sucrose and $\mathrm{NaCl}$ (from $0.25 \mathrm{M}$ sucrose, $13 \mathrm{~g} \mathrm{l}^{-1} \mathrm{NaCl}$ in $0.2 \mathrm{M}$ sodium cacodylate to $0.35 \mathrm{M} \mathrm{NaCl}$ in $0.2 \mathrm{M}$ sodium cacodylate) and post-fixed for $1 \mathrm{~h}$ at $4{ }^{\circ} \mathrm{C}$ in $1 \%$ osmium tetroxide buffered in $0.2 \mathrm{M}$ of sodium cacodylate and $0.33 \mathrm{M} \mathrm{NaCl}$. Samples were then rinsed three times for $15 \mathrm{~min}$ using $0.35 \mathrm{M} \mathrm{NaCl}$ and $0.2 \mathrm{M}$ sodium cacodylate. Dehydratation was carried out in a graded alcohol series (from 30 to 100\%) and samples were finally embedded in Epon. Sections were cut using diamant knifes on a Leica ultracut UCT ultramicrotome and after staining with $2 \%$ uranyl acetate for $10 \mathrm{~min}$ and $2 \%$ lead citrate for $3 \mathrm{~min}$, the grids were examined with a Jeol 1400 TEM (Jeol, Tokyo, Japan). Micrographs were taken using a Gatan Orius camera. 
Cell cultures. THP-1 cells were obtained from Cell Lines Service; HeLa, Jurkat (clone E6-1), and hTERT RPE-1 cells from the American Type Culture Collection (ATCC). Spodoptera frugiperda Sf9 cells were obtained from ATCC and Drosophila melanogaster S2 cells as a gift from Dr. Lucas Waltzer (Centre de Biologie du Développement, Toulouse, France). HeLa, Jurkat, and THP-1 cells were grown at $37^{\circ} \mathrm{C}\left(5 \% \mathrm{CO}_{2}\right)$ in RPMI 1640 medium (Life Technologies, Gibco) with $10 \%$ fetal bovine serum (FBS). hTERT RPE-1 cells were cultured in Dulbecco's modified Eagle's medium (DMEM, Gibco) supplemented with 10\% FBS. Sf9 cells were maintained in Sf-900 II SFM medium (Gibco) supplemented with 1\% FBS. S2 cells were grown in $1 \times$ Schneider's Drosophila medium (Gibco) supplemented with $10 \%$ FBS and 50,000 units $\mathrm{l}^{-1}$ of penicillin and $50,000 \mu \mathrm{g} \mathrm{l}^{-1}$ of streptomycin. Insect cells were kept in a humidified incubator operated at $27^{\circ} \mathrm{C}$. Cell density was determined by cell counting using a Malassez counting chamber (Preciss; Strasbourg, France).

Cell viability. Cells were seeded at a concentration of $3 \times 10^{3}$ cells per well in 96 well plates with or without the indicated concentrations of proteins in triplicate. When indicated, zVAD-fmk, a general caspase inhibitor (BD Biosciences) and staurosporine, an initiator of apoptosis (S6942, $1 \mathrm{mM}$ stock solution, SigmaAldrich) were used at a 50 and $1 \mu \mathrm{M}$ final concentration. After incubation at $27^{\circ} \mathrm{C}$ for the indicated time, 0.1 volume of Alamar Blue (Invitrogen) was added and the cells were incubated at $27^{\circ} \mathrm{C}$ for an additional $3 \mathrm{~h}$. Fluorescence (excitation, 530-560 nm; emission, $590 \mathrm{~nm}$ ) was measured using a microplate reader (TECAN spark $10 \mathrm{M}$ ). Results are presented as a percentage of viable cells relative to experimental control (set as 100\%).

Cell cycle analysis. Cell cycle analysis of HeLa and Jurkat cells was performed by propidium iodide (PI) staining ${ }^{51}$. Briefly, purified nigritoxin or an identical volume of protein solubilization buffer was added to triplicate $25 \mathrm{~cm}^{2}$ flasks containing $3 \times$ $10^{5} \mathrm{HeLa}$ or Jurkat cells in $5 \mathrm{ml}$ of medium $(1.2 \mu \mathrm{M}$ final protein concentration). The cells were then incubated at $37^{\circ} \mathrm{C}$ for $12 \mathrm{~h}$ in a humidified atmosphere of $5 \%$ carbon dioxide in air. Thereafter, HeLa cells were removed from the flasks by trypsinization. Jurkat and HeLa cells were then washed with PBS and fixed with $70 \%$ ice-cold ethanol at $4{ }^{\circ} \mathrm{C}$ for $2 \mathrm{~h}$. The fixed cells were washed with PBS and incubated in the dark with PI/RNase staining buffer (BD Pharmingen) for $30 \mathrm{~min}$. The percentages of a minimum of $7.0 \times 10^{3}$ cells at each stage of the cell cycle were quantitated based on excitation at $488 \mathrm{~nm}$ and emission at $670 \mathrm{~nm}$ (FACS Canto II Flow cytometer, Becton Dickinson, San Jose, CA, USA). The data were analyzed using FCS Express software (De Novo Software).

Caspase activity assay. Sf9 and S2 cell protein extracts for caspase activity were prepared from $1 \mathrm{ml}$ of pelleted control or treated cells at the indicated times. Cell pellets were suspended in $200 \mu \mathrm{l}$ ice-cold buffer A (100 mM HEPES-NaOH, pH $7.5,10 \mathrm{mM}$ dithiothreitol), homogenized by short sonication ( $5 \mathrm{~s}$ pulse, amp. 40 ), and centrifuged at $14,000 \times \mathrm{g}$ for $15 \mathrm{~min}$ at $4^{\circ} \mathrm{C}$ to obtain cytosolic extracts. Caspase assays were carried out in triplicate at $20^{\circ} \mathrm{C}$ for $3 \mathrm{~h} \mathrm{in} 1 \mathrm{ml}$ buffer $\mathrm{A}$, containing $100 \mu \mathrm{g}$ protein extracts and $10 \mu \mathrm{M}$ acetyl-DEVD-4-methyl-coumaryl-7-amide (AcDEVD-MCA) substrate (BD Bioscience). The fluorogenic product substrate was detected at the end of the incubation by excitation at $380 \mathrm{~nm}$ and emission at 480 $\mathrm{nm}$ with a microplate reader (TECAN spark $10 \mathrm{M}$ ).

Antibodies. The antibody against nigritoxin was developed by Eurogentec (Brussels) by injecting one rabbit with $4 \times 100 \mu \mathrm{g}$ purified 6 His-tagged nigritoxin and collecting the serum after 28 days (1:100 for immunofluorescence and 1:1000 for Western blotting). Antibodies against the following molecules were used for immunofluorescence or Western blotting: Alexa Fluor 488 donkey $\alpha$-rabbit IgG $(\mathrm{H}$ $+\mathrm{L}$; A-21206, Invitrogen, 1:500), actin (20-33) (A5060, Sigma, 1:1000) and peroxidase-conjugated rabbit immunoglobulins (P0217, Dako, 1:5000).

Immunofluorescence. Cells were washed once with PBS and fixed for $30 \mathrm{~min}$ at RT with a solution containing $3.7 \%$ paraformaldehyde and $0.2 \%$ Triton X-100. After washing in PBS for $5 \mathrm{~min}$, the cells were then incubated for $1 \mathrm{~h}$ at $25^{\circ} \mathrm{C}$ with the anti-nigritoxin polyclonal antibody at a 1:100 dilution in PBS supplemented with $1 \%$ BSA. After incubation at $4{ }^{\circ} \mathrm{C}$ for $12 \mathrm{~h}$ and four times washing with PBS, cells were incubated with the anti-rabbit secondary antibody conjugated to Alexa Fluor 488 (Invitrogen) at a dilution of 1:500 in PBS containing 1\% BSA for $45 \mathrm{~min}$ in the dark. Following three times washing with PBS, slides were mounted using VECTASHIELD Mounting Medium with DAPI (Vector Laboratories). Slides were analyzed and images collected using an inverted Leica laser-scanning confocal microscope TCS SP5 AOBS (Leica Microsystems, Heidelberg, Germany) with argon laser for illumination or using a Zeiss Axio Observer microscope (Zeiss, France). Observations were made using $63 \times$ N.A. 1.4 objective lens.

Western blot analysis. Reduced samples were prepared in $5 \times$ Laemmli buffer (62.5 mM Tris- $\mathrm{HCl}, \mathrm{pH} 6.8$, with $2 \%$ SDS, $20 \%$ glycerol, $5 \% \beta$-mercaptoethanol, and $0.01 \%$ bromophenol blue), heated at $95{ }^{\circ} \mathrm{C}$ for $5 \mathrm{~min}$, separated by SDS-PAGE and transferred onto nitrocellulose membranes using the Trans-Blot Turbo Transfer System (Bio-Rad), followed by incubation in blocking buffer $(1 \times$ TBS with $0.1 \%$ Tween-20 (TBS-T), $5 \%$ milk) for $45 \mathrm{~min}$. Blots were incubated for $1 \mathrm{~h}$ in primary antibody diluted in TBS-T (1:1000), washed three times with TBS-T, then incubated in secondary antibody diluted in TBS-T (1:5000) for $1 \mathrm{~h}$. Membranes were washed three times with TBS-T, and blots were developed using the Clarity Western ECL Blotting Substrate (Bio-Rad), following manufacturer's instructions.

Data availability. The nigritoxin structure that supports the findings of this study has been deposited in the protein data bank (PDB) under the accession code 5M41. All other data are available from the corresponding author upon reasonable request.

Received: 18 January 2017 Accepted: 14 September 2017 Published online: 01 November 2017

\section{References}

1. Budd, G. E. \& Telford, M. J. The origin and evolution of arthropods. Nature 457, 812-817 (2009).

2. Giribet, G. \& Edgecombe, G. D. Reevaluating the arthropod tree of life. Аnпи. Rev. Entomol. 57, 167-186 (2012).

3. Regier, J. C. et al. Arthropod relationships revealed by phylogenomic analysis of nuclear protein-coding sequences. Nature 463, 1079-1083 (2010).

4. Medlock, J. M. \& Leach, S. A. Effect of climate change on vector-borne disease risk in the UK. Lancet Infect. Dis. 15, 721-730 (2015).

5. Mishra, M. et al. Ecological turmoil in evolutionary dynamics of plant-insect interactions: defense to offence. Planta 242, 761-771 (2015).

6. Ogden, N. H. \& Lindsay, L. R. Effects of climate and climate change on vectors and vector-borne diseases: ticks are different. Trends Parasitol. 32, 646-56 (2016).

7. Richter, S. The Tetraconata concept: hexapod-crustacean relationships and the phylogeny of Crustacea. Org. Divers. Evol. 2, 217-237 (2002).

8. Goudenege, D. et al. Comparative genomics of pathogenic lineages of Vibrio nigripulchritudo identifies virulence-associated traits. ISME J. 7, 1985-1996 (2013).

9. Le Roux, F. et al. Virulence of an emerging pathogenic lineage of Vibrio nigripulchritudo is dependent on two plasmids. Environ. Microbiol. 13, 296-306 (2011).

10. Goarant, C. et al. "Summer Syndrome" in Litopenaeus stylirostris in New Caledonia: pathology and epidemiology of the etiological agent, Vibrio nigripulchritudo. Aquaculture 253, 105-113 (2006).

11. Sakai, T. et al. Mass mortality of cultured kuruma prawn Peneaus japonicus caused by Vibrio nigripulchritudo. Fish Pathol. 42, 141-147 (2007).

12. Hurst, M. R., Beard, S. S., Jackson, T. A. \& Jones, S. M. Isolation and characterization of the Serratia entomophila antifeeding prophage. FEMS Microbiol. Lett. 270, 42-48 (2007).

13. Jank, T. et al. Tyrosine glycosylation of Rho by Yersinia toxin impairs blastomere cell behaviour in zebrafish embryos. Nat. Commun. 6, 7807 (2015).

14. Nagai, H. et al. Novel proteinaceous toxins from the nematocyst venom of the Okinawan sea anemone Phyllodiscus semoni Kwietniewski. Biochem. Biophys. Res. Commun. 294, 760-763 (2002).

15. Ueda, A., Nagai, H., Ishida, M., Nagashima, Y. \& Shiomi, K. Purification and molecular cloning of SE-cephalotoxin, a novel proteinaceous toxin from the posterior salivary gland of cuttlefish Sepia esculenta. Toxicon 52, 574-581 (2008).

16. Nielsen-LeRoux, C., Gaudriault, S., Ramarao, N., Lereclus, D. \& Givaudan, A. How the insect pathogen bacteria Bacillus thuringiensis and Xenorhabdus/ Photorhabdus occupy their hosts. Curr. Opin. Microbiol. 15, 220-231 (2012).

17. Ekert, P. G., Silke, J. \& Vaux, D. L. Caspase inhibitors. Cell Death Differ. 6, 1081-1086 (1999).

18. Lemichez, E. \& Barbieri, J. T. General aspects and recent advances on bacterial protein toxins. Cold Spring Harb. Perspect. Med. 3, a013573 (2013).

19. Galan, J. E. Common themes in the design and function of bacterial effectors. Cell Host Microbe 5, 571-579 (2009).

20. Manning, A. J. \& Kuehn, M. J. Functional advantages conferred by extracellular prokaryotic membrane vesicles. J. Mol. Microbiol. Biotechnol. 23, 131-141 (2013).

21. Bischofberger, M., Gonzalez, M. R. \& van der Goot, F. G. Membrane injury by pore-forming proteins. Curr. Opin. Cell Biol. 21, 589-595 (2009).

22. Krakauer, T. PI3K/Akt/mTOR, a pathway less recognized for staphylococcal superantigen-induced toxicity. Toxins 4, 1343-1366 (2012).

23. Campa, V. M. et al. Endocytosis as a biological response in receptor pharmacology: evaluation by fluorescence microscopy. PLoS ONE 10, e0122604 (2015).

24. Irannejad, R. \& von Zastrow, M. GPCR signaling along the endocytic pathway. Curr. Opin. Cell Biol. 27, 109-116 (2014). 
25. Guerra, L., Cortes-Bratti, X., Guidi, R. \& Frisan, T. The biology of the cytolethal distending toxins. Toxins 3, 172-190 (2011)

26. Fuchs, Y. \& Steller, H. Live to die another way: modes of programmed cell death and the signals emanating from dying cells. Nat. Rev. Mol. Cell Biol. 16, 329-344 (2015)

27. ffrench-Constant, R. H., Dowling, A. \& Waterfield, N. R. Insecticidal toxins from Photorhabdus bacteria and their potential use in agriculture. Toxicon 49, 436-451 (2007)

28. Pardo-Lopez, L., Soberon, M. \& Bravo, A. Bacillus thuringiensis insecticidal three-domain Cry toxins: mode of action, insect resistance and consequences for crop protection. FEMS Microbiol. Rev. 37, 3-22 (2013).

29. Lee, C. T. et al. The opportunistic marine pathogen Vibrio parahaemolyticus becomes virulent by acquiring a plasmid that expresses a deadly toxin. Proc. Natl Acad. Sci. USA 112, 10798-10803 (2015).

30. Brown, S. E. et al. Txp40, a ubiquitous insecticidal toxin protein from Xenorhabdus and Photorhabdus bacteria. Appl. Environ. Microbiol. 72, 1653-1662 (2006).

31. Brown, S. E., Cao, A. T., Hines, E. R., Akhurst, R. J. \& East, P. D. A novel secreted protein toxin from the insect pathogenic bacterium Xenorhabdus nematophila. J. Biol. Chem. 279, 14595-14601 (2004).

32. Chougule, N. P. \& Bonning, B. C. Toxins for transgenic resistance to hemipteran pests. Toxins 4, 405-429 (2012).

33. Studier, F. W. Protein production by auto-induction in high density shaking cultures. Protein Expr. Purif. 41, 207-234 (2005).

34. Groisillier, A. et al. MARINE-EXPRESS: taking advantage of high throughput cloning and expression strategies for the post-genomic analysis of marine organisms. Microb. Cell Fact. 9, 45 (2010).

35. Ficko-Blean, E. et al. Biochemical and structural investigation of two paralogous glycoside hydrolases from Zobellia galactanivorans: novel insights into the evolution, dimerization plasticity and catalytic mechanism of the GH117 family. Acta Crystallogr. D Biol. Crystallogr. 71, 209-223 (2015).

36. Powell, H. R. The Rossmann Fourier autoindexing algorithm in MOSFLM Acta Crystallogr. D Biol. Crystallogr. 55, 1690-1695 (1999).

37. Leslie, A. G. W. Recent changes to the MOSFLM package for processing film and image plate data. Joint CCP4 + ESF-EAMCB Newsletter. Protein Crystallogr 26, 27-33 (1992).

38. Evans, P. Scaling and assessment of data quality. Acta Crystallogr. D Biol. Crystallogr. 62, 72-82 (2006).

39. Evans, P. R. An introduction to data reduction: space-group determination, scaling and intensity statistics. Acta Crystallogr. D Biol. Crystallogr. 67, 282-292 (2011).

40. Collaborative Computational Project, N. TheCCP4 suite: programs for protein crystallography. Acta Crystallogr. D Biol. Crystallogr. 50, 760-763 (1994).

41. Schneider, T. R. \& Sheldrick, G. M. Substructure solution with SHELXD. Acta. Crystallogr. D Biol. Crystallogr. 58, 1772-1779 (2002).

42. Cowtan, K. Fitting molecular fragments into electron density. Acta Crystallogr. D Biol. Crystallogr. 64, 83-89 (2008).

43. Cowtan, K. The Buccaneer software for automated model building. 1. Tracing protein chains. Acta Crystallogr. D Biol. Crystallogr. 62, 1002-1011 (2006).

44. Vagin, A. A. et al. REFMAC5 dictionary: organization of prior chemical knowledge and guidelines for its use. Acta Crystallogr. D Biol. Crystallogr. 60, 2184-2195 (2004).

45. Emsley, P., Lohkamp, B., Scott, W. G. \& Cowtan, K. Features and development of Coot. Acta Crystallogr. D Biol. Crystallogr. 66, 486-501 (2010).

46. Poitout, S. \& Bues, R. Élevage de plusieurs espèces de Lépidoptères Noctuidae sur milieu artificiel riche et sur milieu artificiel simplifié. Ann. Zool. Ecol. Anim. 2, 79-91 (1970).

47. Sicard, M. et al. Stages of infection during the tripartite interaction between Xenorhabdus nematophila, its nematode vector, and insect hosts. Appl. Environ. Microbiol. 70, 6473-6480 (2004).

48. Finney, D. J. Probit Analysis (Cambridge University Press, 1952).
49. Munoz, M. et al. Involvement of penaeidins in defense reactions of the shrimp Litopenaeus stylirostris to a pathogenic vibrio. Cell. Mol. Life Sci. 61, 961-972 (2004).

50. Lepelletier, F. et al. Dinomyces arenysensis gen. et sp. nov. (Rhizophydiales, Dinomycetaceae fam. nov.), a chytrid infecting marine dinoflagellates. Protist 165, 230-244 (2014).

51. Le Bouffant, R., Cormier, P., Cueff, A., Belle, R. \& Mulner-Lorillon, O. Sea urchin embryo as a model for analysis of the signaling pathways linking DNA damage checkpoint, DNA repair and apoptosis. Cell. Mol. Life Sci. 64, 1723-1734 (2007).

52. Nosenko, T. et al. Deep metazoan phylogeny: when different genes tell different stories. Mol. Phylogenet. Evol. 67, 223-233 (2013).

\section{Acknowledgements}

We are indebted to the European Synchrotron Research Facilities (ESRF, Grenoble, France) for regular access to X-ray beamlines and to all local contacts for their support during data collection at the MX beamline ID29. We also thank the French synchrotron at SOLEIL (St. Aubin) for regular access to the MX beamline PX2, and especially William Shepard, Gavin Fox, and Martin Savko (SOLEIL-St. Aubin) for valuable help during the X-ray data collection and data treatment. We thank Dr. Lucas Waltzer (Centre de Biologie du Développement, Toulouse, France) for providing the S2 cell line. We thank the staff of the station Ifremer Nouvelle Caledonie, the M3 service of the Station Biologique of Roscoff, Nathalie Desban, Florence Solari, Christophe Lambert, and Dominique Marie for technical support. We warmly thank Brigid Davis (HMS, Boston, USA) and Melanie Blokesch (EPFL, Lausanne Switzerland) for fruitful discussions and critically reading the manuscript. The present study has been supported by the ANR (11-BSV7023-01 $<<$ VIBRIOGEN $>>$ and 13-ADAP-0007-01 <<OPOPOP $>>$ ).

\section{Author contributions}

Y.L., S.C., A.J., V.B., D.A., S.L.P., and S.P. performed experiments. M.C. performed the protein structure determination and analyses. Y.L., A.G., M.C., and F.L.R. designed experiments, interpreted results, and wrote the paper.

\section{Additional information}

Supplementary Information accompanies this paper at doi:10.1038/s41467-017-01445-Z.

Competing interests: The authors declare no competing financial interests.

Reprints and permission information is available online at http://npg.nature.com/ reprintsandpermissions/

Publisher's note: Springer Nature remains neutral with regard to jurisdictional claims in published maps and institutional affiliations.

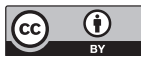

Open Access This article is licensed under a Creative Commons Attribution 4.0 International License, which permits use, sharing, adaptation, distribution and reproduction in any medium or format, as long as you give appropriate credit to the original author(s) and the source, provide a link to the Creative Commons license, and indicate if changes were made. The images or other third party material in this article are included in the article's Creative Commons license, unless indicated otherwise in a credit line to the material. If material is not included in the article's Creative Commons license and your intended use is not permitted by statutory regulation or exceeds the permitted use, you will need to obtain permission directly from the copyright holder. To view a copy of this license, visit http://creativecommons.org/ licenses/by/4.0/.

(C) The Author(s) 2017 